\title{
Evaluation of biomarkers in plasma, blood, and urine samples from coke oven workers: significance of exposure to polycyclic aromatic hydrocarbons
}

\author{
Steinar Øvrebø, Aage Haugen, Peter B Farmer, Denise Anderson
}

\begin{abstract}
Objective-The aim was to assess the significance of two biomarkers; antibody to benzo(a)pyrene DNA adducts and concentration of hydroxyethylvaline haemoglobin adducts in samples from a well studied group of coke oven workers. As a measure of exposure we have used 1hydroxypyrene in urine.

Methods-Urine and blood samples were collected from coke oven workers and a control group. Samples from coke oven plant workers were collected in January and June. 1-Hydroxypyrene was measured in urine by high performance liquid chromatography (HPLC), antibodies to benzo(a)pyrene DNA adducts were measured by ELISA and hydroxyethylvaline haemoglobin adducts were measured by gas chromatography-mass spectrometry (GC-MS).
\end{abstract}

Results-Mean urinary 1-hydroxypyrene in samples from coke oven workers varied from 1.11 to 5.53 umol/mol creatinine and $0.14 \mathrm{umol} / \mathrm{mol}$ creatinine in the control group. Workers at the top side had the highest values of urinary 1-hydroxypyrene. Antibody to benzo(a)pyrene DNA adducts did not correlate with either 1-hydroxypyrene nor length of work at the coke oven plant. But antibody concentration in samples collected in January was predictive of the concentration in samples collected in June. A small non-significant increase in hydroxyethylvaline haemoglobin adducts was found in samples from coke oven workers relative to the control group when comparing smokers and nonsmokers separately.

Conclusion-1-Hydroxypyrene correlates well with exposure groups based on job description. Antibodies to benzo(a)pyrene DNA adducts was related to people and not exposure. Work at a coke oven plant might lead to increased hydroxyethylvaline haemoglobin adducts.

(Occup Environ Med 1995;52:750-756)

Keywords: polycyclic aromatic hydrocarbons; biomarkers; antibodies to adducts

Occupational exposure to polycyclic aromatic hydrocarbons (PAHs) is encountered in coke oven plants, electrochemical industry, electrode factories, and in various manufacturing plants with combustion processes. Several PAH compounds are potent carcinogens and working in coke production, aluminum production, and other processes with PAH exposure is thought to carry an increased risk of cancer. ${ }^{12}$ There is a general interest in development and evaluation monitoring methods for exposure and effects of exposure to ensure reliable health surveillance at work places with PAH exposure. ${ }^{34}$

Measurement of 1-hydroxypyrene in urine has been shown to be a reasonably reliable method for monitoring of PAH exposure, , $^{5-8}$ and has been used as an exposure estimate for evaluating other methods. ${ }^{9-11}$

There is considerable interest in studying associations between exposure markers or effect indicators and cancer in workers occupationally exposed to PAHs. ${ }^{12-14}$ Benzo(a)pyrene is metabolically activated to benzo(a)pyrenediolepoxide (BPDE), which can react with DNA resulting in benzo(a)pyrene DNA adducts. It has been shown in humans who are occupationally exposed to high concentrations of PAHs, ${ }^{15}$ or moderate amounts of PAH in the environment, ${ }^{17}$ that about $40 \%$ have antibodies to benzo(a)pyrene DNA adducts. Antibodies to other PAH DNA adducts have also been found, ${ }^{17}$ and in experiments after chronic PAH exposure in mice antibodies to benzo(a)pyrene DNA adducts have been detected. ${ }^{18}$ Occupational exposure to antigenic compounds has been extensively studied mainly for hypersensitivity. ${ }^{19} 20$ But the far reaching implications of antibodies to carcinogenic compounds have not yet been established, although a general association between carcinogenesis and immunoresponses has been discussed. ${ }^{21}$

Exposure to ethylene oxide leads to formation of hydroxyethylvaline haemoglobin adducts $^{22}$ and smoking increases the concentration of these adducts. ${ }^{23} \mathrm{~A}$ background level of hydroxyethylvaline adducts in haemoglobin has been established and smoking and occupational exposure to ethylene oxide have been shown to increase this background level by up to about 10-fold and 300-fold respectively. ${ }^{24} 25$ Studies have also been conducted in several polluted areas in search of variations due to environmental pollution. ${ }^{26}$ In coke oven plants many compounds are formed, which gives a harmful working environment. Methylating agents have been detected as a result of combustion processes ${ }^{27}$ and therefore it is likely that other alkylating agents will be present at coke oven plants, although we are not aware of 
any reports that show this.

We have measured 1-hydroxypyrene in urine from coke oven workers and a control group and analysed the association between urinary 1-hydroxypyrene and antibodies to benzo(a)pyrene DNA adducts and measured hydroxyethylvaline haemoglobin adducts. We found a possible association between PAH exposure and hydroxyethylvaline adducts in haemoglobin. Antibodies to benzo(a)pyrene DNA adducts did not correlate with exposure, but were person related judged from samples collected at two time periods.

\section{Materials and method \\ MATERIALS}

1-Hydroxypyrene was from Jansen Chimica, Beerse, Belgium. A mixture of glucuronidase and sulphatase were purchased from Boehringer, Mannheim, Germany. Methanol, high performance liquid chromatography (HPLC) grade, was from Fluka Chimica Buchs, Switzerland. Anti-human immunoglobulin G (IgG) ( $\gamma$-chain specific) with alkaline phosphatase goat and calf thymus DNA was obtained from Sigma, St Louis, Montana, USA. Benzo(a)pyrene-r-7,t-8dihydrodiol-t-9,10-epoxide $( \pm$ ) (BPDE) was obtained from NCI Chemical Carcinogen Control Standard Repositories, Bethesda, Maryland and Kansas City, Missouri, USA.

\section{STUDY GROUP}

All workers participating in this study were recruited on a voluntary basis. The workers were divided into exposure groups based on job category. Top side workers were assigned to the high exposure group, side oven workers to the medium exposure group, and maintenance workers to the low exposure group. Table 1 describes the groups. All biological samples have been stored at $-20^{\circ} \mathrm{C}$. Blood and urine samples were collected after the shift on working days.

\section{MEASUREMENT OF 1-HYDROXYPYRENE IN WORKERS' URINE}

The method used for measurement of 1hydroxypyrene in urine was performed essentially as described by Jongeneelen et al..$^{5}$ Urine was diluted with acetic acid, $\mathrm{pH}$ adjusted, and incubated for 16 hours after addition of an enzyme mixture of glucuronidase and sulphatase. This mixture was applied on a Sep-Pak C-18 cartridge with the help of a Lab robot, Millilab, Waters, Milford, Massachusetts, USA. The cartridges were washed with water and then eluted with $4 \mathrm{ml}$ of methanol. Of the eluate $20 \mu \mathrm{l}$ was injected

Table 1 Distribution of variables in the exposure groups

\begin{tabular}{|c|c|c|c|c|}
\hline \multirow[b]{2}{*}{ Groups } & \multicolumn{2}{|c|}{ Subjects (n) } & \multirow{2}{*}{$\begin{array}{l}\text { Arithmetic } \\
\text { mean } \\
(S D) \text { age }\end{array}$} & \multirow{2}{*}{$\begin{array}{l}\text { Smokers (\%) } \\
(S D)\end{array}$} \\
\hline & fanuary & fune & & \\
\hline $\begin{array}{l}\text { Control } \\
\text { Low exposure } \\
\text { Medium exposure } \\
\text { High exposure }\end{array}$ & $\begin{array}{l}13 \\
23 \\
26 \\
18\end{array}$ & $\begin{array}{l}\overline{17} \\
18 \\
13\end{array}$ & $\begin{array}{l}48 \cdot 8(9.9) \\
38.3(9.5) \\
36.7(11.6) \\
33.4(10.7)\end{array}$ & $\begin{array}{l}46 \cdot 1(51 \cdot 9) \\
56 \cdot 1(50 \cdot 2) \\
61 \cdot 4(49 \cdot 3) \\
50 \cdot 0(50 \cdot 9)\end{array}$ \\
\hline
\end{tabular}

into an HPLC with a Novapak $\mathrm{C}_{18}$ column. The elution was with a methanol/water gradient and detection with a fluorescence detector (Perkin-Elmer, Beaconsfield, UK) at $242 \mathrm{~nm}$ ( $\lambda$ excitation) and $288 \mathrm{~nm}$ ( $\lambda$ emission). Five spiked control urine samples were used as standards with addition of $10,20,40,100$ and $250 \mathrm{nmol} / 1$ 1-hydroxypyrene. Measurement was performed with Millennium integration software.

\section{MEASUREMENT OF ANTIBODIES IN HUMAN PLASMA DIRECTED TO BENZO(A)PYRENE DNA ADDUCTS}

As a test for antibodies to benzo(a)pyrene DNA adducts we have measured the binding to benzo(a)pyrenediolepoxide (BPDE) modified calf thymus DNA and in the text we have used the term antibody to benzo(a)pyrene DNA adducts for this activity. The measurements were performed essentially according to the method described by Newman. ${ }^{17}$ Microtitre plates of polyvinylchloride Fastbinder 6695 (Costar Europe, Badhoevedorp, the Netherlands) were coated with $80 \mathrm{ng}$ DNA/well of either calf thymus DNA or BPDE modified calf thymus $(9,4$ fmol BPDE/ng DNA). Calf thymus DNA was modified with BPDE essentially as described by Newman. ${ }^{17}$ The DNA was arranged on the plates in triplets of calf thymus DNA and triplets of BPDE modified calf thymus DNA. Coating of plates was done with DNA diluted in $20 \times$ standard saline citrate (SSC) which was added to the plates and incubated for 16 hours at $37^{\circ} \mathrm{C}$ and thereafter stored at $-20^{\circ} \mathrm{C}$ in closed containers until use. The plates were washed with distilled water twice, before the addition of $4 \%$ bovine serum albumin in phosphate buffered saline (PBS) at $\mathrm{pH} 7 \cdot 4$ for one hour to minimise unspecific binding. The plasma samples were diluted 1:25 with $4 \%$ bovine serum albumin in PBS and $50 \mu \mathrm{l}$ was added to triplet wells with BPDE modified calf thymus DNA and triplet wells with calf thymus DNA and incubated for 1.5 hours at $37^{\circ} \mathrm{C}$. Then goat anti-human IgG was added (diluted 1:5000) and the plates incubated for two hours. Then the plates were washed twice with $0.2 \mathrm{M}$ diethanolamine before addition of $5 \mathrm{mg}$ p-nitrophenylphosphate dissolved in $10 \mathrm{ml} 0.2 \mathrm{M}$ diethanolamine and incubated for one hour. Each sample was added to three wells with BPDE modified calf thymus DNA and three wells with calf thymus DNA. The difference in mean value between the triplicate with modified DNA and triplicate with calf thymus DNA was tested with a $t$ test, and if the difference was significant at the 0.05 level the sample was considered positive. In each plate a standard sample was included and all positive values were calculated as percentages of this standard. The samples were assayed three times on different plates, and the mean value was calculated.

\section{MEASUREMENT OF HYDROXYETHYLVALINE IN} HAEMOGLOBIN

The method used for the measurement of hydroxyethylvaline in haemoglobin was that of 
Bailey et $a l^{28}$ with minor modifications. Globin was prepared from red blood cells by the procedure of Bailey et al..$^{29}$ Aliquots of globin (50 mg) were mixed with the internal standard (globin that had been reacted with $\mathrm{d}_{4}$-ethylene oxide). This internal standard contained $25 \cdot 7$ nmol $\mathrm{d}_{4}$-hydroxyethylvaline/mg protein, and the amount added to each sample contained $77 \mathrm{pmol} \mathrm{d}_{4}$-hydroxyethylvaline. The globin was dissolved in formamide solution $(2 \mathrm{ml})$ and subjected to an Edman type degradation, with pentafluorophenyl isothiocyanate $(10 \mu \mathrm{l})$ as reagent. Pyridine $(7 \mu \mathrm{l})$ was also added and the mixture shaken gently overnight at room temperature and then heated to $45^{\circ} \mathrm{C}$ for 90 minutes. The product was purified by Sep-Pak C-18 cartridge chromatography and then converted to the trimethylsilyl derivative by reaction with $\mathrm{N}, \mathrm{O}$-bis(trimethylsilyl)trifluoroacetamide $(20 \mu \mathrm{l})$ in acetonitrile $(30 \mu \mathrm{l})$ at $60^{\circ} \mathrm{C}$ for 30 minutes. The sample was dried, redissolved in acetonitrile $(30 \mu \mathrm{l})$, and subjected to GC-MS analysis with electron impact ionisation. Measurement was achieved by selected ion recording of ions $\mathrm{m} / \mathrm{z} 440$ and $\mathrm{m} / \mathrm{z} 444$ (for $\mathrm{d}_{0}$-and $\mathrm{d}_{4}$-hydroxyethylvaline derivatives respectively). The mass spectrometer was a VG Trio 1 quadruple instrument coupled to a Hewlett-Packard 5890 Series II gas chromatograph. The GC column was $25 \mathrm{~m} \times 0.32 \mathrm{~mm}$, coated with SE52 or a similar stationary phase. With each batch of samples analysed a calibration line was established with mixtures of unlabelled and $\mathrm{d}_{4}$-labelled ethylene oxide treated globin.

\section{STATISTICS}

The three main variables in this study were urinary 1-hydroxypyrene, antibodies to benzo(a)pyrene DNA adducts, and hydroxyethylvaline adducts in haemoglobin. All these

Figure 1 Box plot describing urinary 1hydroxypyrene from coke oven workers divided into groups based on anticipated PAH exposure. The urine samples were collected in Fanuary and in fune. For a description of the groups see table 1.

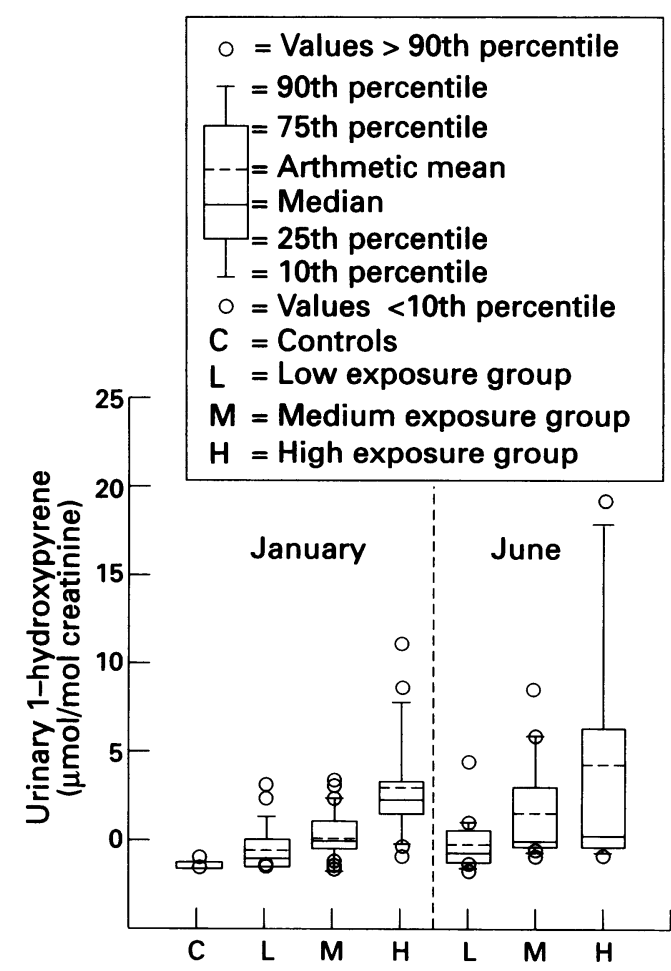

Table 2 1-Hydroxypyrene in urine from coke oven workers divided into groups based on exposure and sampling time

\begin{tabular}{llllll}
\hline & \multicolumn{3}{l}{ Mean values $(\mu$ mol/g creatinine) } \\
\cline { 2 - 3 } & Arithmetic & & \multicolumn{2}{l}{ Geometric } \\
\cline { 2 - 3 } \cline { 5 - 6 } Groups & fanuary & fune & & fanuary & fune \\
\hline Control & 0.14 & - & & 0.11 & - \\
Low & 1.11 & 1.32 & & 0.67 & 0.81 \\
Medium & 1.80 & 2.93 & & 1.30 & 2.17 \\
High & 4.26 & 5.53 & & 3.42 & 3.07 \\
\hline
\end{tabular}

Table 3 1-Hydroxypyrene in urine from coke oven workers divided into groups based on smoking

\begin{tabular}{|c|c|c|c|c|}
\hline \multirow[b]{3}{*}{ Groups } & \multicolumn{4}{|c|}{ Mean values ( $\mu$ mol/g creatinine) } \\
\hline & \multicolumn{2}{|c|}{ Arithmetic } & \multicolumn{2}{|l|}{ Geometric } \\
\hline & fanuary & fune & fanuary & fune \\
\hline Control & 0.08 & - & 0.07 & - \\
\hline $\begin{array}{l}\text { Control } \\
\text { smokers } \\
\text { Exposed }\end{array}$ & 0.22 & - & $0 \cdot 17$ & - \\
\hline non-smokers & $2 \cdot 23$ & $2 \cdot 35$ & $1 \cdot 22$ & $1 \cdot 44$ \\
\hline smokers & $2 \cdot 16$ & $3 \cdot 55$ & $1 \cdot 40$ & $1 \cdot 86$ \\
\hline
\end{tabular}


Table 4 Antibody to benzo(a)pyrene DNA adducts in plasma from coke oven workers

\begin{tabular}{|c|c|c|c|c|}
\hline \multirow[b]{2}{*}{ Groups } & \multicolumn{2}{|c|}{ Samples (n) } & \multicolumn{2}{|c|}{$\begin{array}{l}\text { Arithmetic mean of } \\
\text { antibodies (relative units) }\end{array}$} \\
\hline & All & $\begin{array}{l}\text { Positive* } \\
n(\%)\end{array}$ & All & Positive \\
\hline $\begin{array}{l}\text { Samples Jan } \\
\text { Control } \\
\text { Low } \\
\text { Medium } \\
\text { High }\end{array}$ & $\begin{array}{l}13 \\
23 \\
26 \\
18\end{array}$ & $\begin{array}{r}6(46 \cdot 2) \\
14(60 \cdot 9) \\
12(46 \cdot 2) \\
12(66 \cdot 7)\end{array}$ & $\begin{array}{r}6 \cdot 44 \\
10 \cdot 19 \\
4 \cdot 30 \\
3 \cdot 68\end{array}$ & $\begin{array}{r}13 \cdot 96 \\
16 \cdot 74 \\
9 \cdot 32 \\
5 \cdot 51\end{array}$ \\
\hline $\begin{array}{l}\text { Samples Jun } \\
\text { Low } \\
\text { Medium } \\
\text { High }\end{array}$ & $\begin{array}{l}18 \\
18 \\
12\end{array}$ & $\begin{array}{l}9(50 \cdot 0) \\
7(38 \cdot 9) \\
4(33 \cdot 3)\end{array}$ & $\begin{array}{r}14 \cdot 80 \\
3.91 \\
1 \cdot 39\end{array}$ & $\begin{array}{r}29 \cdot 59 \\
10 \cdot 06 \\
4 \cdot 17\end{array}$ \\
\hline $\begin{array}{l}\text { Non-smoker } \\
\text { Control } \\
\text { Low } \\
\text { Medium } \\
\text { High }\end{array}$ & $\begin{array}{r}7 \\
9 \\
10 \\
10\end{array}$ & $\begin{array}{l}2(28 \cdot 6) \\
4(44 \cdot 4) \\
7(70 \cdot 0) \\
6(60 \cdot 0)\end{array}$ & $\begin{array}{l}0 \cdot 76 \\
2 \cdot 09 \\
6 \cdot 85 \\
3 \cdot 53\end{array}$ & $\begin{array}{l}2 \cdot 67 \\
4 \cdot 71 \\
9 \cdot 79 \\
5 \cdot 89\end{array}$ \\
\hline $\begin{array}{l}\text { Non-smoker } \\
\text { Low } \\
\text { Medium } \\
\text { High }\end{array}$ & $\begin{array}{l}9 \\
7 \\
5\end{array}$ & $\begin{array}{l}5(55 \cdot 6) \\
3(42 \cdot 9) \\
1920 \cdot 0)\end{array}$ & $\begin{array}{l}2 \cdot 74 \\
7 \cdot 01 \\
0 \cdot 20\end{array}$ & $\begin{array}{r}4.93 \\
16 \cdot 36 \\
1.00\end{array}$ \\
\hline
\end{tabular}

*All values used were greater than 0 .
Table 5 Regression analysis of IgG antibody to benzo (a) pyrene DNA adducts at two time points (data from the fune sampling were used as dependent variable)

\begin{tabular}{|c|c|c|c|c|}
\hline & Estimate & $P$ value & $\begin{array}{l}R^{2} \text { for } \\
\text { regression } \\
(\%)\end{array}$ & $n$ \\
\hline $\begin{array}{l}\text { All values: } \\
\text { Intercept } \\
\text { Slope }\end{array}$ & $\begin{array}{r}-0.83 \\
1.18\end{array}$ & $\begin{array}{c}0.24 \\
<0.0001\end{array}$ & 96.8 & 46 \\
\hline $\begin{array}{c}\text { Only positive } \\
\text { Intercept } \\
\text { Slope }\end{array}$ & $\begin{array}{l}-1.61 \\
1 \cdot 19\end{array}$ & $\begin{array}{c}0.58 \\
<0.0001\end{array}$ & 97.6 & 10 \\
\hline
\end{tabular}

Table 6 Correlation (Pearson) between concentration of antibodies to benzo (a) pyrene DNA adducts and to DNA*

\begin{tabular}{llll}
\hline & & $\begin{array}{l}\text { Anti DNA } \\
\text { (fanuary) }\end{array}$ & $\begin{array}{l}\text { Anti DNA } \\
\text { (fune) }\end{array}$ \\
\hline Anti B(a)P DNA & January) & $\begin{array}{l}0.55 \dagger \\
(43) \ddagger\end{array}$ & - \\
& & $0.0002 \S$ & 0.69 \\
Anti B(a)P DNA & June) & - & $\begin{array}{l}0.60) \\
(20) \\
\end{array}$ \\
& & 0.0008
\end{tabular}

*Calculation performed on selected positive log transformed data; fcorrelation coefficient; $\ddagger$ sample size; $§ P$ value.

medium exposure groups in the January sampling and medium and high exposure in the June sampling. Table 2 shows arithmetic and geometric mean. In the control group there was a significant difference between smokers and non-smokers for urinary 1-hydroxypyrene. There was no such significant difference between the exposed smokers and non-smokers. But the arithmetic and geometric means show a larger increase in the exposed group than the differences found in the control group except for the arithmetic mean in the January samples (table 3).

The division into exposure groups explains part of the variation in urinary 1-hydroxypyrene as already shown. The mean values were higher among the workers who used protective masks. There was a negative correlation between urinary 1-hydroxypyrene and age and a positive correlation between exposure groups and age-that is, there was an overrepresentation of young workers in the high exposure group. Regression analysis of 1hydroxypyrene in urine from workers sampled in June as the dependent variable and January as the independent variable resulted in an

intercept of 0.27 and slope of $0.47, \mathrm{P}=$ 0.0002 and $R^{2} 27 \%$. This analysis was performed on log transformed data and the parameters are given directly from the analysis.

\section{ANTIBODY TO BENZO(A)PYRENEDIOLEPOXIDE} MODIFIED DNA

Factors likely to influence formation of antibodies to benzo(a)pyrene modified DNA are $\mathrm{PAH}$ exposure, duration of work with $\mathrm{PAH}$ exposure, smoking, and age. No significant correlations were found between amount of antibody and any of these factors. Table 4 shows a more detailed analysis of the effect of exposure. As there are several values equal to 0 the geometric mean is 0 and is therefore not shown. The only potential dose response of exposure can be seen in the group of nonsmokers (January sampling), but the sample size was small. Otherwise no systematic tendency can be seen.

By analysing the dependency of IgG antibody in the June samples on the values found in the January samples we found a high correla-
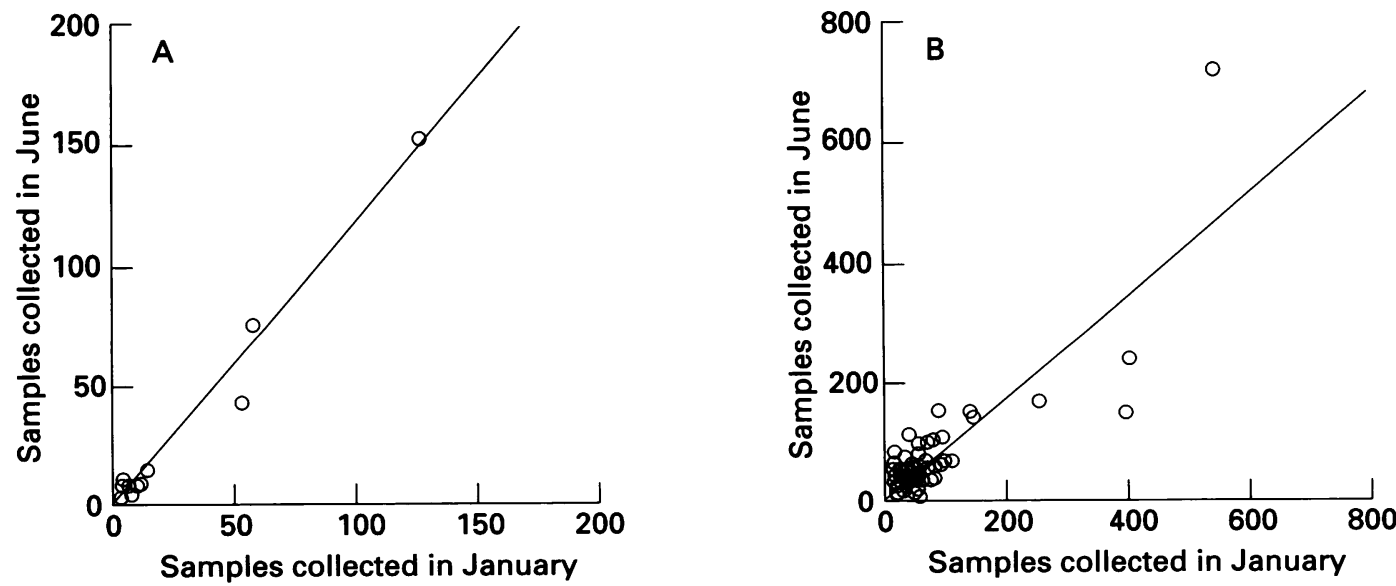

Figure 2 Scatter plots of antibody concentration in fune as the dependent variable and the antibody concentration in samples collected in fanuary as the independent variable with regression lines plotted. $(A)$ Antibodies to benzo(a)pyrene $D N A$ adducts. (B) Antibodies to unmodified calf thymus DNA. 
Table 7 Hydroxyethylvaline bound to haemoglobin in samples from coke oven workers and a control group

\begin{tabular}{|c|c|c|c|c|c|c|}
\hline \multirow[b]{2}{*}{ Group } & \multicolumn{4}{|c|}{ Hydroxyethylvaline (pmollg haemoglobin) } & \multirow{2}{*}{$\begin{array}{l}\text { 1-Hydroxy- } \\
\text { pyrene } \\
\text { (mean) }\end{array}$} & \multirow{2}{*}{$\begin{array}{l}\text { Workers } \\
\text { age } \\
\text { (mean) }\end{array}$} \\
\hline & $n$ & Mean (SD) & Median & $\begin{array}{l}\text { Interquartile } \\
\text { range }\end{array}$ & & \\
\hline $\begin{array}{l}\text { Non-smokers } \\
\text { Smokers }\end{array}$ & $\begin{array}{r}11 \\
9\end{array}$ & $\begin{array}{c}49 \cdot 1(25 \cdot 0) \\
256 \cdot 8(128 \cdot 9)\end{array}$ & $\begin{array}{r}40 \cdot 6 \\
270 \cdot 2\end{array}$ & $\begin{array}{r}30 \cdot 5 \\
185 \cdot 9\end{array}$ & $\begin{array}{l}2 \cdot 18 \\
2 \cdot 36\end{array}$ & $\begin{array}{l}43 \cdot 0 \\
44 \cdot 3\end{array}$ \\
\hline $\begin{array}{l}\text { Non-exposed non-smokers } \\
\text { Exposed non-smokers }\end{array}$ & $\begin{array}{l}6 \\
5\end{array}$ & $\begin{array}{l}42 \cdot 2(16 \cdot 2) \\
57 \cdot 3(32 \cdot 8)\end{array}$ & $\begin{array}{l}39 \cdot 5 \\
49 \cdot 2\end{array}$ & $\begin{array}{l}17 \cdot 0 \\
29 \cdot 6\end{array}$ & $\begin{array}{l}0 \cdot 08 \\
4 \cdot 69\end{array}$ & $\begin{array}{l}52 \cdot 7 \\
31 \cdot 4\end{array}$ \\
\hline $\begin{array}{l}\text { Non-exposed smokers } \\
\text { Exposed smokers }\end{array}$ & $\begin{array}{l}4 \\
5\end{array}$ & $\begin{array}{l}211.7(103.6) \\
293.0(146.7)\end{array}$ & $\begin{array}{l}208 \cdot 0 \\
270 \cdot 2\end{array}$ & $\begin{array}{l}178 \cdot 5 \\
181 \cdot 0\end{array}$ & $\begin{array}{l}0 \cdot 13 \\
4 \cdot 13\end{array}$ & $\begin{array}{l}52 \cdot 0 \\
38 \cdot 2\end{array}$ \\
\hline
\end{tabular}

tion. For this regression analysis about $97 \%$ of the variation could be explained both when analysis was done on all measured samples and on selected sample pairs with only positive values (table 5). Figure 2(A) shows a regression plot for samples with positive values of IgG antibody to benzo(a)pyrene modified DNA. A similar regression analysis was done on data from IgG antibodies to calf thymus DNA (fig $2(B)$ ), the regression coefficient was 0.82 and intercept $11 \cdot 1, \mathrm{P}<0.0001, R^{2} 73 \%$. If the three highest values in fig $2(\mathrm{~A})$ were deleted, $R^{2}$ was reduced to $64 \%$, and if the four highest values in fig 2(B) were deleted $R^{2}$ was reduced to $65 \%$. There was also an association between antibodies to benzo(a)pyrene modified DNA and antibodies to DNA (table 6).

\section{HYDROXYETHYLVALINE BOUND TO} HAEMOGLOBIN

Hydroxyethylvaline was analysed in 20 haemoglobin samples collected in January, 10 from the control group and 10 from the highly exposed group, 10 were smokers and 10 nonsmokers. There was a significant difference between the concentration of hydroxyethylvaline in haemoglobin among the smokers and the non-smokers $z=3.72$ (Mann-Whitney U test, $P=0.0002$ )

Hydroxyethylvaline data were analysed for correlation with urinary 1-hydroxypyrene, exposure group, smoking, age, and years worked at the plant. Only smoking gave a significant correlation coefficient equal to 0.78 (P $=0.0001$, Pearson product moment).

Table 7 shows the actual values. There were higher hydroxyethylvaline adducts in both PAH exposed groups when we divided them into smokers and non-smokers and compared them with control groups of smokers and nonsmokers. The differences were not significant. But the sample size was small.

\section{Discussion}

The urinary 1-hydroxypyrene results are comparable with previously published results at coke oven plants. ${ }^{611}$ Our 1-hydroxypyrene data correlates well with expected exposure based on job descriptions, and workers at the top side of the oven have the highest values as expected (also found by others). ${ }^{6}$ But it should be noted that even among the workers at the top side several workers were found with low urinary 1-hydroxypyrene (fig 1). It is interesting to see that urinary 1-hydroxypyrene values measured in the June samples can partly be explained by values found in January. This shows that sampling only once gives a fairly good estimate of the exposure at such a plant.

Measurements of 1-hydroxypyrene mirrors the exposure in the short term, about 24 hours, ${ }^{32}$ whereas PAH DNA adducts have a longer half life and are therefore likely to be the result of exposure from a much longer time period, at least several weeks. ${ }^{33}$ With this background, correlation between adducts and urinary 1-hydroxypyrene would be less likely. Recent reports have found no association, ${ }^{9}$ or a weak association ${ }^{34}$ between adducts and urinary 1-hydroxypyrene.

Antibodies to benzo(a)pyrene modified DNA were first measured in serum from coke oven workers, ${ }^{1516}$ where about $30 \%$ of the workers had such antibodies. Unexposed control groups were not included in these studies. Later Newmann and coworkers studied a nonoccupationally exposed group and found antibodies in serum from about $40 \%$ of the workers, ${ }^{17}$ which is comparable with the data from coke oven workers, and indicates that coke oven workers are not more prone to have high antibody concentrations than non-occupationally exposed people. Our study, with a control group exposed to low concentrations of PAHs, clearly confirms the above indication that high PAH exposure has no effect or only a marginal effect upon formation of antibodies to benzo(a)pyrene DNA adducts. Similar results have been found in a study among foundry workers ${ }^{35}$ and patients treated with coal tar. ${ }^{36}$ The influence of number of years worked at a coke oven has also been analysed and no significant association has been found, ${ }^{16}$ which also supports our findings.

We cannot offer any good explanation why some people have high concentrations of antibody to benzo(a)pyrene DNA adducts, but it is likely to be due to some personal factor, either genetic, or environmental, or both. As we found a high correlation between antibodies to benzo(a)pyrene DNA adducts and antibodies to pure DNA (table 6) a genetic component may be possible. One could dispute this correlation as the analysis for antibodies to DNA and for antibodies to benzo(a)pyrene DNA adducts was done with the same analysis, but the high concentration of antibodies to DNA should decrease the concentration found for antibodies to BPDE modified DNA. Passive smoking and industrial pollution during infancy could induce some lasting formation of antibody. We have no information on these factors, but the studied population does live in an industrialised region. We are planning a follow up of this analysis. The plant has 
been closed for several years and it would be interesting to investigate if the same people still have high concentration of these antibodies.

Ethylene oxide has been identified in atmospheric air samples as a result of combustion of hydrocarbon fuels. ${ }^{27}$ It is therefore not unlikely that coke oven workers will be exposed to hydroxyethylating agents. The established fact that cigarette smoking increases hydroxyethylvaline in haemoglobin complicates the analysis of the possible effect of the workplace. The increase due to work at the coke oven plant was about $7 \%$ to $40 \%$ of the difference we found between smokers and non-smokers, and therefore not important as a risk factor compared with the concentrations found among workers occupationally exposed to ethylene oxide. ${ }^{225}$ To unequivocally analyse the possible contribution from work at a coke oven plant one should study non-smokers in a larger group than we have investigated here.

In summary, we have measured urinary 1hydroxypyrene concentrations in different working groups at a coke oven plant. We have established new evidence that coke oven workers do not have increased amounts of antibody to benzo(a)pyrene DNA adducts compared with a control group. We have presented evidence that the quantity of antibodies to benzo(a)pyrene DNA adducts are person related, possibly genetic. Hydroxyethylvaline adducts in haemoglobin were increased among coke oven workers, but were not significant.

We thank Dr H Hofstad Andreassen for sampling and administration of questionnaires at the plant. The technical assistance of tration of questionnaires at the plant. The technical assistance of An Deverill and Ingrid V Botnen is gratefully acknowledged. Thanks to Dr Mark J Newman for advice with the assay for
antibodies to benzo(a)pyrene DNA. We have used chemicals from the NCI repository in this study. This study has been partly supported by STEP grant No EV5V-CT91-0013(MNLA).

1 LARC monographs on the evaluation of the carcinogenic risk of chemicals to humans, Polynuclear aromatic compounds, vol 32, part 3. Industrial exposures in aluminium production, coal gasification, coke production, and iron and steel founding. Lyon:International Agency for Research on Cancer, 1984 .

2 LARC monographs on the evaluation of the carcinogenic risk of chemicals to humans. Polynuclear aromatic compounds, vol chemicals to humans. Polynuclear aromatic compounds, vol 32, part 1. Chemical, environmental and experimental data. Lyon:

3 Beach AC, Gupta RC. Human biomonitoring and the ${ }^{32} \mathrm{P}-$ postlabeling assay. Carcinogenesis 1992;13:1053-74

4 dell'Omo $M$, Lauwerys $R R$. Adducts to macromolecules in the biological monitoring of workers exposed to poly-
cyclic aromatic hydrocarbons. Crit Rev Toxicol 1993;23: 111-26.

5 Jongeneelen FJ, Anzion RBM, Henderson PT. Determination of hydroxylated metabolites of polycyclic
aromatic hydrocarbons in urine. $\mathcal{F}$ Chromatogr 1987;413: aromatic $227-32$.

6 Jongeneelen FJ, Van Leeuwen FE, Oosterink S, Anzion RBM, Van der Loop F, Bos RP, Van Veen HG. Ambient and biological monitoring of cokeoven workers: determiand biological monitoring of cokeoven workers: determi-
nants of the internal dose of polycyclic aromatic hydro-

7 VanRooij JGM, Bodelier-Bade MM, De Looff AJA, Dijkmans APG, Jongeneelen FJ. Dermal exposure to polycyclic aromatic hydrocarbons among aluminium workers. Med Lav 1992;83:519-29.

8 Vähäkangas K, Pyy L, Yrjänheikki E. Assessment of PAHexposure among coke oven workers. Pharmacogenetics 1992;2:304-8.

9 Øvrebø S, Haugen A, Fjeldstad PE, Hemminki K, Szyfter $\mathrm{K}$. Biological monitoring of exposure to polycyclic aromatic hydrocarbon in an electrode paste plant. $尹$ Occup Med 1994;36:303-10.

10 Beland FA, Poirier MC. Significance of DNA adduct studies in animal models for cancer molecular dosimetry and risk assessment. Environ Health Perspect 1993;99:5-10.
11 Ferreira MJ, Buchet JP, Burrion JB, Moro J, Cupers L, Delavignette JP, et al. Determinants of urinary thioethers, D-glucaric acid and mutagenicity after exposure to polycyclic aromatic hydrocarbons assessed by air monitoring and measurement of 1-hydroxypyrene in urine: a crosssectional study in workers of coke and graphite-electrode-producing plants. Int Arch Occup Environ Health 1994;65:329-38.

12 Lohman PHM, Morolli B, Darroudi F, Natarajan AT, Gossen JA, Venema J, et al. Contributions from molecular/biochemical approaches in epidemiology to cancer risk assessment and prevention. Environ Health Perspect risk assessment and

13 Gaylor DW, Kadlubar FF, Beland FA. Application of biomarkers to risk assessment. Environ Health Perspect 1992;98:139-41.

14 Strickland PT, Routledge MN, Dipple A. Methodologies for measuring carcinogen adducts in humans. Cancer Epidemiol Biomarkers Prev 1993;2:607-19.

15 Haugen A, Becher G, Benestad C, Vähäkangas K, Triver GE, Newman MJ, Harris CC. Determination of polycyclic aromatic hydrocarbons in the urine, benzo(a)pyrene diol epoxide-DNA adducts in lymphocyte DNA, and antibodies to the adducts in sera from coke oven workers exposed to measured amounts of polycyclic aromatic hydrocarbons in the work atmosphere. Cancer Res 1986;46:4178-83.

16 Harris CC, Vähäkangas $\mathrm{K}$, Newman MJ, Trivers GE, Shamsuddin A, Sinopoli N, et al. Detection of benzo(a)pyrene diol epoxide-DNA adducts in peripheral blood lymphocytes and antibodies to the adducts in serum from coke oven workers. Proc Natl Acad Sci USA 1985;82:6672-6.

17 Newman MJ, Light BA, Weston A, Tollurud D, Clark JL, Mann DL, et al. Detection and characterization of human serum antibodies to polycyclic aromatic hydrocarbon diol-epoxide DNA adducts. $\mathcal{F}$ Clin Invest 1988; 82:145-53.

18 Lee BM, Strickland PT. Antibodies to carcinogen-DNA adducts in mice chronically exposed to polycyclic aromatic hydrocarbons. Immunology 1993;36:117-24.

19 Grammer LC, Shaughnessy MA, Davis RA. Exposure to TMXDI $R$ (meta) aliphatic isocyanate and TMI $R$ TMXDI $R$ (meta) aliphatic isocyanate and TMI R
(meta) unsaturated aliphatic isocyanate. $f$ Occup Med (meta) unsatura

20 Sandven $P$, Eduard $W$. Detection and quantitation of antibodies against Rhizopus by enzyme-linked immunosorbent assay. APMIS 1992;100:981-7.

21 Weliky N, Heiner DC. A common pathway for chemicalinduced tissue injury and immune responses leading to hypersensitivity and/or carcinogenesis. Med Hypothesis 1985;16:69-91.

22 Farmer PB, Bailey E, Gorf SM, Törnqvist M, OstermanGolkar S, Kautiainen A, Lewis-Enright DP. Monitoring human exposure to ethylene oxide by the determination of haemoglobin adducts using gas chromatography-mass spectrometry. Carcinogenesis 1986;7:637-40.

23 Törnqvist M, Osterman-Golkar S, Kautiainen A, Jensen S, Farmer PB, Ehrenberg L. Tissue doses of ethylene oxide Farmer PB, Ehrenberg $L$. Tissue doses of ethylene oxide
in cigarette smokers determined from adduct levels in in cigarette smokers determined from adduct
hemoglobin. Carcinogenesis 1986;7:1519-21.

24 Farmer PB, Bailey E, Naylor S, Anderson D, Brooks A, Cushnir $\mathrm{J}$, et al. Identification of endogenous electrophiles by means of mass spectrometric determination of protein and DNA adducts. Environ Health Perspect 1993;99:19-24.

25 Tates AD, Grummt T, Törnqvist M, Farmer PB, van Dam FJ, van Mossel $\mathrm{H}$, et al. Biological and chemical monitoring of occupational exposure to ethylene oxide. Mutat Res 1991;250:483-97.

26 Cordero R, Conduah J, Autrup H, Garner RC, Haugen A, Waters R, Farmer PB. N-terminal N-(2-hydroxyethyl)valine in human hemoglobin [abstract]. Proceedings of the valine in human hemoglobin [abstract]. Proceedings of

27 LARC monographs on the evaluation of the carcinogenic risk of chemicals to humans, vol 36. Allyl compounds, aldehydes, epoxides, and peroxides. Lyon: International Agency for Research on Cancer, 1984

28 Bailey E, Farmer PB, Tang Y-S, Vangikar H, Gray A, Slee $\mathrm{D}$, Ings RMJ, et al. Hydroxylation of hemoglobin by 1 (2-chloroethyl)-1-nitrosoureas. Chem Res Toxicol 1991;4: $462-6$.

29 Bailey E, Brooks AGF, Dollery CT, Farmer PB, Passingham BJ, Sleightholm MA, Yates DW. Hydroxyethylvaline adduct formation in haemoglobin as a biological monitor of cigarette smoke intake. Arch Toxicol 1988; 62:247-53.

30 Øvrebø S, Haugen A, Phillips DH, Hewer A. Detection of polycyclic aromatic hydrocarbon-DNA adducts in white
blood cells from coke oven workers: correlation with job blood cells from coke oven workers: co

31 Herikstad B, Øvrebø S, Haugen A, Hagen I. Determination of polycyclic aromatic hydrocarbons in urine from coke-oven plant workers with radioimmunoassay Carcinogenesis 1993;14:307-9.

32 Jongeneelen FJ, Anzion RBM, Scheepers PTJ, Bos RP, Henderson PT, Nijenhuis EH, et al. 1-Hydroxypyrene in urine as a biological indicator of exposure to polycyclic aromatic hydrocarbons in several work environments. Ann Occup Hyg 1988;32:35-43.

33 Lu L-JW, Anderson LM, Jones AB, Moskal TJ, Salazar JJ, Hokanson JA, Rice JM. Persistence, gestation stagedependent formation and interrelationship of benzo(a) pyrene-induced DNA adducts in mothers, placentae and 
fetuses of Erythrocebus patas monkeys. Carcinogenesis 1993;14:1805-13.

34 Santella RM, Hemminki K, Tang D-L, Paik M, Ottman R Young TL, et al. Polycyclic aromatic hydrocarbon-DNA adducts in white blood cells and urinary 1-hydroxypyrene in foundry workers. Cancer Epidemiol Biomarkers Prev 1993;2:59-62.

35 Santella RM, Li Y, Young TL, Stefanidis M, Lu XQ, Lee $\mathbf{B M}$, et al. Immunological methods for the detection of polycyclic aromatic hydrocarbon-DNA and protein adducts. In: Waters $\mathrm{M}$, ed. Genetic toxicology of complex mixtures. New York: Plenum Press, 1990:291-301.

36 Santella RM, Perera FP, Young TL, Zhang Y-J, Chiamprasert S, Tang D, et al. Polycyclic aromatic hydrocarbon-DNA and protein adducts in coal tar treated patients and controls and their relationship to glutathione S-transferase genotype. Mutat Res 1995;334: 117-24.

\section{Vancouver style}

All manuscripts submitted to Occup Environ Med should conform to the uniform requirements for manuscripts submitted to biomedical journals (known as the Vancouver style.)

Occup Environ Med, together with many other international biomedical journals, has agreed to accept articles prepared in accordance with the Vancouver style. The style (described in full in the BMF, 24 February $1979, \mathrm{p}$ 532) is intended to standardise requirements for authors.

References should be numbered consecutively in the order in which they are first mentioned in the text by Arabic numerals above the line on each occasion the reference is cited (Manson ${ }^{1}$ confirmed other reports $^{2-5}$. . .). In future references to papers submitted to Occup Environ Med should include: the names of all authors if there are seven or less or, if there are more, the first six followed by et al; the title of journal articles or book chapters; the titles of journals abbreviated according to the style of Index Medicus; and the first and final page numbers of the article or chapter. Titles not in Index Medicus should be given in full.

Examples of common forms of references are:

1 International Steering Committee of Medical Editors, Uniform requirements for manuscripts submitted to
biomedical journals. $B r M e d ~ \mathcal{f} 1979 ; 1: 532-5$.

2 Soter NA, Wasserman SI, Austen KF. Cold urticaria: release into the circulation of histamine and eosinophil chemotactic factor of anaphylaxis during cold challenge. N Engl f Med 1976;294:687-90.

3 Weinstein L, Swartz MN. Pathogenic properties of invading micro-organisms. In: Sodeman WA Jr, Sodeman WA, eds. Pathologic physiology, mechanism of disease. Philadelphia: $\mathbb{W}$ B Saunders, 1974:457-72. 